\title{
Entrepreneurial Culture in the Village of the Barbers, Garut, Indonesia
}

\author{
Nizar Alam Hamdani, Galih Abdul Fatah Maulani, Arif Abdullah Muharam
}

\begin{abstract}
Garut is not only well-known as the city of dodol, but also as the city of the barbers. Most barbermen in Indonesia come from Garut, precisely from a village named Kampung Parung, Banyuresmi Subdistrict. Usually, upon completion of high schools, they go to big cities to open barbershops instead of going to universities. This has been a well-established entrepreneurial culture in that village for decades. The purpose of this study is to identify how this long entrepreneurial culture is established. To this end, a survey was addressed to 120 barbermen. The results show that family plays an important role in establishment of entrepreneurial culture in the village in question. Education is not much of importance to them.
\end{abstract}

Keywords: Entrepreneurial Culture; Entrepreneurship, Village of the Barbers.

\section{INTRODUCTION}

Entrepreneurship is a very important factor in the economic development of a country (1) so that communities with entrepreneurial culture will always plays an essential role in it (2). In today's global competition, countries with a strong entrepreneurial structure have a competitive advantage in international trade. Therefore, it is very necessary to promote understanding about entrepreneurial culture $(3,4)$.

In 2018, the total number of entrepreneurs in Indonesia is $3.1 \%$ of its total working age population (5). According to the 2018 Global Entrepreneurship Index, Indonesia ranks 94th out of 137 countries in the world (6).

Table 1. The 2018 GEI Ranks Within the Asia-Pacific Region

\begin{tabular}{lll}
\hline Country & Ranks & GEI \\
\hline Australia & 1 & $75 \%$ \\
\hline Hongkong & 2 & $67 \%$ \\
\hline Singapore & 5 & $53 \%$ \\
\hline China & 9 & $41 \%$ \\
\hline Brunei Darussalam & 10 & $34 \%$ \\
\hline Malaysia & 11 & $33 \%$ \\
\hline India & 14 & $28 \%$ \\
\hline Philippines & 17 & $24 \%$ \\
\hline Vietnam & 18 & $23 \%$ \\
\hline Indonesia & 21 & $21 \%$ \\
\hline
\end{tabular}

Revised Manuscript Received on April 19, 2019.

Nizar Alam Hamdani, Economic Faculty, Universitas Garut, West Java, Indonesia.

Galih Abdul Fatah Maulani, Entrepreneurship Faculty, Universitas Garut, West Java, Indonesia.

Arif Abdullah Muharam, Research Deparment, Institut Pendidikan Indonesia Garut, West Java, Indonesia.
The above data shows that the entrepreneurial culture in Indonesia is rather low. This is particularly restricted, according to the 2018 GEI report, by risk retention in doing entrepreneurship (6). However, on a national scale, Indonesia experienced an increase in the level of entrepreneurship from $1.67 \%$ to $3.10 \%$ of the total Indonesian population of 225 million (7). Garut, West Java, is a region in Indonesia with rapid entrepreneurial growth. Garut has not only been known as the city of dodol, but also as the home of Indonesian barbermen. Most of top-notch barbers across the country come from Garut, particularly from the Village of Banyuresmi and the Village of Bagendit (8). For people in these two villages, becoming a barber has been an entrepreneurial culture passed down ever since the Dutch colonization era (9). This paper describes factors that contribute to the establishment of this entrepreneurial culture.

\section{LITERATURE REVIEW}

Studies show that entrepreneurship and culture are two inseparable entities $(2,10,11)$. Culture is a general picture of society in certain groups and is transmitted from generation to generation (12).

Entrepreneurship in a society always makes a dynamic influence on certain moral values that shape culture in the society in question (2). There are several factors contributing to the establishment of entrepreneurial culture in a society including environmental factor $(1,13)$, education (14), economy (15), income level, family factor, and kinship factor (2).

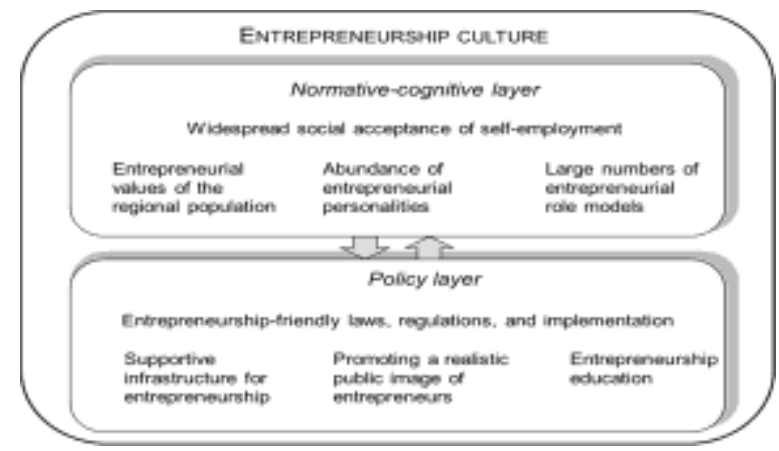

Figure 1. Elements of an entrepreneurial culture (16). 
International Conference on Recents Advancements in Engineering and Technology (ICRAET-18) |15th and 16th March 2019|Siddhartha Institute of Technology \& Sciences, Telangana, India.

\section{METHODOLOGY/MATERIALS}

This study was conducted using a quantitative survey. Data were collected through questionnaires addressed to 120 barbermen in the Village of Banyuresmi, the Village of Bagendit, and some other areas in Garut. Data analysis was performed using PLS-SEM. The survey attempted to examine the influence of entrepreneurial motivation, family environment, and technology on the entrepreneurial decision.

\section{RESULTS AND FINDINGS}

Based on the data we collected, we found that $100 \%$ of barbers in Garut were male. Their average income ranged from IDR 5 to 6 million.

Further analysis was conducted using PLS-SEM. The purpose was to examine the influence of entrepreneurial motivation, family environment, and technology on the entrepreneurial decision. Figure 2 is the resulting modeling.

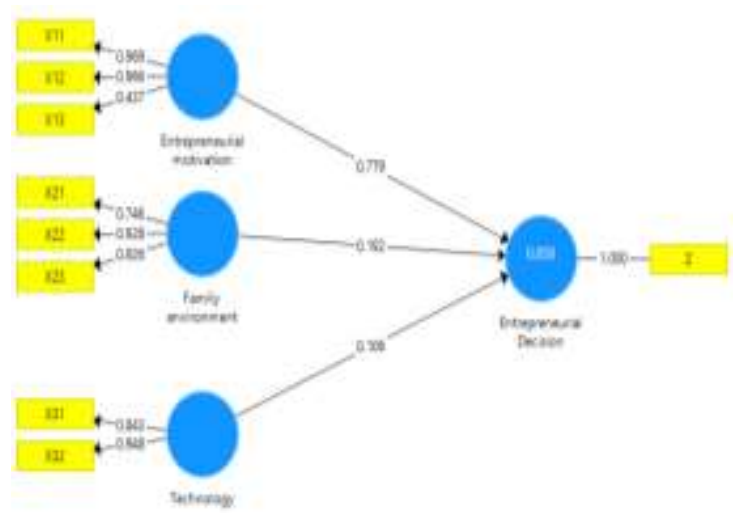

Figure 2 PLS Modeling

Figure 2 can be interpreted as follows:

a. Entrepreneurial motivation has influence on entrepreneurial decision as much as 0.779 or $77.9 \%$ and the factor loadings of entrepreneurial motivation indicators, which include social factor (X11), emotional factor (X12), and educational factor (X13), are 0.969, 0.966, and 0.437 respectively.

b. Family environment has influence on entrepreneurial decision as much as 0.192 or $19.2 \%$ and the factor loadings of family environment indicators, which include family business ownership (X21), family encouragement to do business (X22), and family knowledge about business (X23), are 0.746, 0.928, and 0.926 respectively.

c. Technology has influence on entrepreneurial decision as much as 0.106 or $10.6 \%$ the factor loadings of technology, which include information access through electronic media (X31) and use of ICT devices (X32), were 0.834 and 0.984 .

Based on PLS Algorithm calculation, an indicator can be said reliable if it has a loading value of more than 0.50 . Since educational factor (X13) has a loading value below 0.50 , this indicator should be removed from the PLS modeling.

SmartPLS data processing also resulted in the construct reliability and validity as shown in Table 2 .
Table 2 Construct Reliability and Validity

\begin{tabular}{lcccc} 
& $\begin{array}{l}\text { Cronbach's } \\
\text { Alpha }\end{array}$ & rho_A & $\begin{array}{l}\text { Composite } \\
\text { Reliability }\end{array}$ & $\begin{array}{l}\text { Average } \\
\text { Variance } \\
\text { Extracted } \\
\text { (AVE) }\end{array}$ \\
\hline $\begin{array}{l}\text { Entrepreneurial } \\
\text { Decision }\end{array}$ & 1.000 & 1.000 & 1.000 & 1.000 \\
\hline $\begin{array}{l}\text { Entrepreneurial } \\
\text { motivation }\end{array}$ & 0.749 & 0.936 & 0.857 & 0.688 \\
\hline $\begin{array}{l}\text { Family } \\
\text { environment }\end{array}$ & 0.837 & 0.871 & 0.903 & 0.758 \\
\hline Technology & 0.771 & 0.921 & 0.891 & 0.805 \\
\hline
\end{tabular}

Table 2 shows that all variables can be said to be valid because their AVE values are more than 0.50. All variables can also be said to be reliable as their Cronbach's alpha and composite reliability values are more than 0.7 .

Table 3 presents the result of structural model testing. The $\mathrm{R}$-squared value shows that the studied variables contribute to entrepreneurial decision as much as $85 \%$.

Table 3. R Square

\begin{tabular}{cll}
\hline & R Square & $\begin{array}{c}\text { R Square } \\
\text { Adjusted }\end{array}$ \\
\hline $\begin{array}{c}\text { Entrepreneurial } \\
\text { Decision }\end{array}$ & 0,858 & 0,843 \\
\hline
\end{tabular}

Table 4 summarizes the results of bootstrapping. It shows that the relationships between all studied variables and entrepreneurial decision are positive because their original sample values are all positive.

Table 4. Mean, STDEV, T-Values, P-Values

\begin{tabular}{|c|c|c|c|c|c|}
\hline & $\begin{array}{l}\text { Origina } \\
1 \\
\text { Sample } \\
\text { (O)| }\end{array}$ & $\begin{array}{l}\text { Sample } \\
\text { Mean } \\
\text { (M) }\end{array}$ & $\begin{array}{l}\text { Standard } \\
\text { Deviatio } \\
\mathbf{n} \\
\text { (STDEV) }\end{array}$ & $\begin{array}{l}\text { T Statistics } \\
(\mid \mathrm{O} / \mathrm{STDEV})\end{array}$ & $\begin{array}{l}\mathrm{P} \\
\text { Value } \\
\mathrm{s}\end{array}$ \\
\hline $\begin{array}{l}\text { Entrepreneuria } \\
\text { l motivation -> } \\
\text { Entrepreneuria } \\
\text { 1 Decision }\end{array}$ & 0.800 & 0.800 & 0.077 & 10.425 & 0.000 \\
\hline $\begin{array}{l}\text { Family } \\
\text { environment -> } \\
\text { Entrepreneuria } \\
\text { 1 Decision }\end{array}$ & 0.213 & 0.220 & 0.074 & 2.863 & 0.004 \\
\hline $\begin{array}{l}\text { Technology -> } \\
\text { Entrepreneuria } \\
\text { 1 Decision }\end{array}$ & 0.074 & 0.071 & 0.093 & 0.800 & 0.424 \\
\hline
\end{tabular}

The influence of each variable on entrepreneurial decision ca be said significant if their $t$ statistics values are more than the critical $t$ of 1.96. Therefore, it can be concluded that entrepreneurial motivation and family environment has significant influence on entrepreneurial decision of barbermen in Garut because their t statistics values are more than 1.96; i.e., 10.425 and 2.863. And the other variable, technology, has no significant influence on entrepreneurial decision since its t statistics is 0.800 or below 1.96 .

\section{V.CONCLUSION}

Entrepreneurial culture in Garut has been established by several factors such as social and emotional factors. In addition, the establishment of entrepreneurial culture can also be facilitated by family 
and kinship factors. Therefore, it can be concluded that the decision of people in Garut to choose a career path as barbermen is mostly down to family factor and social and emotional motivation.

\section{REFERENCES}

1. Mirzanti IR, Simatupang TM, Larso D. Mapping on Entrepreneurship Policy in Indonesia. Procedia - Soc Behav Sci [Internet]. 2015;169(August 2014):346-53. Available from: http://dx.doi.org/10.1016/j.sbspro.2015.01.319

2. Duman L, Bedük A, Köylüoğlu AS, Ay K. Entrepreneurship Culture at SMEs: A Case Study in Konya. Procedia - Soc Behav Sci [Internet] 2015;207:492-501. Available from: http://dx.doi.org/10.1016/j.sbspro.2015.10.119

3. Kemal ÖKTEM Mehmet Devrim AYDIN Serdar EKİNCİ M. Sosyo Ekonomi Türkiye'de Girişimciliğin Geliştirilmesinde KOSGEB'in Rolü ve Önemi: Uygulamalı Bir Çalışma The Role and Importance of KOSGEB in Improving the Entrepreneurship in Turkey: A Field Study. 2007;

4. Alam Hamdani N, Abdul Fatah Maulani G. The influence of E-WOM on purchase intentions in local culinary business sector. Int $\mathrm{J}$ Eng Technol. 2018;7(2.29):246

5. Zuraya N. Tingkat Kewirausahaan di Indonesia Rendah [Internet]. www.republika.co.id. 2018. Available from: https://www.republika.co.id/berita/ekonomi/korporasi/18 /10/18/pgsax3383-enggartiasto-tingkat-kewirausahaandi-indonesia-rendah

6. Ács ZJ, Szerb L, Lloyd A. The Global Entrepreneurship Index 2018. 2018.

7. P W. Jumlah Pengusaha di Indonesia Meningkat, Tapi.. [Internet]. koinworks.com. 2018. Available from: https://koinworks.com/blog/jumlah-pengusaha-diindonesia-meningkat/

8. Supriadin J. Banyuresmi, Kampung Sekolah Tukang Cukur Andal Indonesia [Internet]. www.liputan6.com. 2017. p. 1. Available from: https://www.liputan6.com/regional/read/2968462/banyur esmi-kampung-sekolah-tukang-cukur-andal-indonesia

9. Teguh I. Ada Apa di Balik Banyaknya Juru Pangkas Rambut Asli Garut? [Internet]. tirto.id. 2019. p. 1. Available from: https://tirto.id/ada-apa-di-balikbanyaknya-juru-pangkas-rambut-asli-garut-deL7

10. Şahin TK, Asunakutlu T. Entrepreneurship in a Cultural Context: A Research on Turks in Bulgaria. Procedia Soc Behav Sci. 2014;150:851-61.

11. Castaño M, Méndez M, Galindo M-ángel. The effect of social , cultural, and economic factors on entrepreneurship $\hbar$. J J Bus Res [Internet]. 2015;1-5. Available from: http://dx.doi.org/10.1016/j.jbusres.2015.01.040

12. Chaşovschi C, Bordeianu O, Clipa D. Entrepreneurial Culture in Transition Economies. The case of Romania and Republic of Moldova. Procedia Econ Financ. 2014;15(14):1507-14.

13. Seaman C, Bent R, Unis A. Family entrepreneurship culture, entrepreneurial intent, futures and foresight in Scottish Pakistani communities. Futures. 2016;75:83-91.

14. Gavron R. The entrepreneurial society. London: IPPR; 1998.

15. Majocchi A, Presutti M. Industrial clusters, entrepreneurial culture and the social environment: The effects on FDI distribution. Int Bus Rev. 2009;18(1):7688.
16. Fritsch M, Wyrwich M. Persistence of Regional Entrepreneurship: Causes, Effects, and Directions for Future Research. Jena Econ Res Pap. 2017;(April):1-30.

\section{AUTHORS PROFILE}

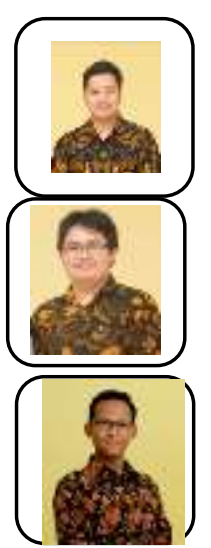

Nizar Alam Hamdani. lecturer at Fakultas Ekonomi Universitas Garut. His research interests include strategic management, knowledge management, entrepreneurship, and SMEs.

Galih Abdul Fatah Maulani. lecturer at Fakultas Kewirausahaan Universitas Garut, Indonesia. His research interests include business information system, strategic management, technopreneurship and information technology...

Arif Abdulllah Muharam. Research Center Institut Pendidikan Indonesia Garut. His research interests include educational technology and entrepreneurship. 